\title{
Atmospheric Carbon Capture Performance of Legacy Iron and Steel Waste
}

\author{
Huw Pullin, ${ }^{*}{ }^{\dagger}$ Andrew W. Bray, ${ }^{\ddagger \odot}$ Ian T. Burke, ${ }^{\ddagger}$ D Duncan D. Muir, ${ }^{\dagger}$ Devin J. Sapsford, ${ }^{\S}$ \\ William M. Mayes, ${ }^{\| \odot}$ and Phil Renforth ${ }^{\perp}$ \\ ${ }^{\dagger}$ School of Earth and Ocean Sciences, Cardiff University, Cardiff CF10 3AT, United Kingdom \\ ${ }^{\ddagger}$ School of Earth and Environment, University of Leeds, Leeds LS2 9JT, United Kingdom \\ ${ }^{\S}$ School of Engineering, Cardiff University, Cardiff CF24 3AA, United Kingdom \\ "Department of Geography, Geology and Environment, University of Hull, Hull HU6 7RX, United Kingdom \\ ${ }^{\perp}$ School of Engineering and Physical Sciences, Heriot-Watt University, Edinburgh EH14 4AS, United Kingdom
}

Supporting Information

ABSTRACT: Legacy iron $(\mathrm{Fe})$ and steel wastes have been identified as a significant source of silicate minerals, which can undergo carbonation reactions and thus sequester carbon dioxide $\left(\mathrm{CO}_{2}\right)$. In reactor experiments, i.e., at elevated temperatures, pressures, or $\mathrm{CO}_{2}$ concentrations, these wastes have high silicate to carbonate conversion rates. However, what is less understood is whether a more "passive" approach to carbonation can work, i.e., whether a traditional slag emplacement method (heaped and then buried) promotes or hinders $\mathrm{CO}_{2}$ sequestration. In this paper, the results of characterization of material retrieved from a first of its kind drilling program on a historical blast furnace slag heap at Consett, U.K., are reported. The mineralogy of the slag

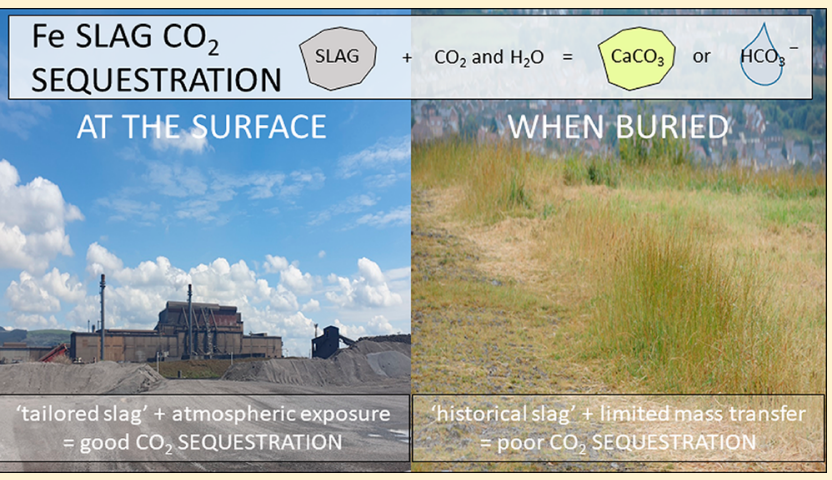
material was near uniform, consisting mainly of melilite group minerals with only minor amounts of carbonate minerals detected. Further analysis established that total carbon levels were on average only $0.4 \%$ while average calcium (Ca) levels exceeded $30 \%$. It was calculated that only $\sim 3 \%$ of the $\mathrm{CO}_{2}$ sequestration potential of the $>30 \mathrm{Mt}$ slag heap has been utilized. It is suggested that limited water and gas interaction and the mineralogy and particle size of the slag are the main factors that have hindered carbonation reactions in the slag heap.

\section{INTRODUCTION}

In 2013, carbon dioxide concentrations in the atmosphere exceeded $400 \mathrm{ppm}$, a significant increase versus pre-Industrial Revolution levels $(280 \mathrm{ppm}) .{ }^{1}$ This continuing anthropogenic influence has an increasing likelihood of severe, pervasive, and irreversible impacts for people and ecosystems. ${ }^{2}$ A Special Report from the Intergovernmental Panel on Climate Change (IPCC) in 2018, ${ }^{3}$ along with numerous scientific academies, ${ }^{4-6}$ suggests that greenhouse gas removal (GGR) from the atmosphere is needed, coupled with an extensive reduction in greenhouse gas emissions to negate the worst of these effects. The amount of $\mathrm{CO}_{2}$ removal is significant, on the order of $100-$ 1000 billion tons (Gt) of $\mathrm{CO}_{2}$ this century. Various GGR options have been proposed, including directly capturing greenhouse gases from the atmosphere, ${ }^{7}$ biomass energy and carbon capture and storage, ${ }^{8}$ and mineral carbonation. latter concept was first proposed in the $1990 \mathrm{~s}^{10,11}$ and mimics natural weathering processes in which calcium or magnesium $(\mathrm{Mg})$ minerals are converted into carbonates. ${ }^{12}$ This idea was extended to alkaline iron and steel slags in the following decade, ${ }^{12-15}$ which also contain a significant source of $\mathrm{Ca}$ and
$\mathrm{Mg}$ silicates and oxides. The minerals in slags (e.g., larnite, $\mathrm{Ca}_{2} \mathrm{SiO}_{4}$, and gehlenite, $\mathrm{Ca}_{2} \mathrm{Al}_{2} \mathrm{SiO}_{7}$ ) can react with atmospheric $\mathrm{CO}_{2}$ that has dissolved into solution, the products of which are thermodynamically stable. ${ }^{11,16,17}$

$$
\begin{aligned}
& \mathrm{Ca}_{2} \mathrm{SiO}_{4(\mathrm{~s})}+2 \mathrm{H}_{2} \mathrm{CO}_{3(\mathrm{aq})} \\
& \rightarrow 2 \mathrm{CaCO}_{3(\mathrm{~s})}+2 \mathrm{H}_{2} \mathrm{O}_{(\mathrm{l})}+\mathrm{SiO}_{2(\mathrm{~s})} \\
& \mathrm{Ca}_{2} \mathrm{Al}_{2} \mathrm{SiO}_{7(\mathrm{~s})}+2 \mathrm{H}_{2} \mathrm{CO}_{3(\mathrm{aq})} \\
& \rightarrow 2 \mathrm{CaCO}_{3(\mathrm{~s})}+\mathrm{Al}_{2} \mathrm{O}_{3(\mathrm{~s})}+2 \mathrm{H}_{2} \mathrm{O}_{(\mathrm{l})}+\mathrm{SiO}_{2(\mathrm{~s})} \\
& \mathrm{Ca}_{2} \mathrm{SiO}_{4(\mathrm{~s})}+4 \mathrm{H}_{2} \mathrm{CO}_{3(\mathrm{aq})} \\
& \rightarrow 2 \mathrm{Ca}\left(\mathrm{HCO}_{3}\right)_{2(\mathrm{aq})}+2 \mathrm{H}_{2} \mathrm{O}_{(\mathrm{l})}+\mathrm{SiO}_{2(\mathrm{~s})}
\end{aligned}
$$

Received: February 28, 2019

Revised: July 15, 2019

Accepted: July 18, 2019

Published: July 18, 2019 


$$
\begin{aligned}
& \mathrm{Ca}_{2} \mathrm{Al}_{2} \mathrm{SiO}_{7(\mathrm{~s})}+4 \mathrm{H}_{2} \mathrm{CO}_{3(\mathrm{aq})} \\
& \quad \rightarrow 2 \mathrm{Ca}\left(\mathrm{HCO}_{3}\right)_{2(\mathrm{aq})}+\mathrm{Al}_{2} \mathrm{O}_{3(\mathrm{~s})}+2 \mathrm{H}_{2} \mathrm{O}_{(\mathrm{l})}+\mathrm{SiO}_{2(\mathrm{~s})}
\end{aligned}
$$

In eqs 1 and 2 , captured $\mathrm{CO}_{2}$ is precipitated as solid carbonate minerals ("mineral carbonation"), e.g., calcite, or, if $\mathrm{Mg}$ is the cation, hydrated magnesium carbonates. ${ }^{18}$ However, if the saturation state with respect to the carbonate mineral is insufficient to induce precipitation, the captured $\mathrm{CO}_{2}$ can be transported to the ocean in the form of dissolved carbonate $\left(\mathrm{CO}_{3}{ }^{2-}\right)$ or, more commonly, bicarbonate $\left(\mathrm{HCO}_{3}{ }^{-}\right)$ions (eqs 3 and 4), where it increases ocean alkalinity ("enhanced weathering"). ${ }^{19}$

World steel output exceeded $1600 \mathrm{Mt}$ in $2017 .{ }^{20}$ In the EU, steel production released $\sim 182 \mathrm{Mt}$ of $\mathrm{CO}_{2}{ }^{21}$ of greenhouse gases, ${ }^{12,22}$ which equated to $4-5 \%$ of the EU's total emissions. However, it is estimated that $470-610 \mathrm{Mt}$ of slag was concurrently produced, which could negate some of these $\mathrm{CO}_{2}$ emissions. ${ }^{23-25}$ Due to the reactive nature of some slag phases, e.g., larnite, ${ }^{12}$ mineral $\mathrm{CO}_{2}$ sequestration is more rapid in slags than in natural silicates, e.g., forsterite $\left(\mathrm{Mg}_{2} \mathrm{SiO}_{4}\right)$; thus, their utilization may incur lower energy consumption and costs. ${ }^{26}$ Value can therefore be added to iron and steel slags that are either landfilled or employed only for low-end applications owing to their low technical performance (tendency to expand) in construction applications. ${ }^{27}$

Slags are named from the furnace from which they are generated, ${ }^{28}$ and there are three predominant forms: blast furnace $(\mathrm{BF})$ slag from the production of iron and basic oxygen furnace (BOF) and electric arc furnace (EAF) slags, both of which are from the production of steel. The mineralogy of these slags depends on the raw minerals used, production methods, and postprocessing practices, ${ }^{28,29}$ and iron and steelworks carefully manipulate these factors to tailor the physical and chemical characteristics of their products. ${ }^{30,31}$ More than 60 different minerals have been identified in iron and steel making slags, the most common of which are listed in Table 1 (for a full version, see Table S1).

Of the slag carbonation studies that have been published, a majority have focused on laboratory-based reactors at high temperatures and/or pressures, ${ }^{32-34}$ short-term experiments (typically hours), ${ }^{12,13,35}$ those with pure $\mathrm{CO}_{2}$ streams, ${ }^{36}$ or those with material that was finer than what was typically industrially produced. $^{35,37,38}$ Other industrial wastes that have been investigated include mafic or ultramafic mining wastes (tailings), ${ }^{39-41}$ although tailings ponds, unlike slag heaps, are rarely covered, and the material has a finer grain size (due to the milling of ores) than slags. A number of papers have addressed the mineralogy of historical iron slags heaps, but these dealt with small, archeological sites (19th Century or earlier). ${ }^{42-44}$

Different engineering approaches have been proposed that can achieve near complete carbon mineralization with alkaline industrial residues, including slags, in well-mixed systems at relatively low $\mathrm{CO}_{2}$ partial pressures and temperatures. ${ }^{45-47}$ This study, however, assesses the mid- to long-term passive carbonation processes occurring in a large, modern, emplaced tip by analyzing material from a novel drilling program on such a site and questions whether this waste emplacement method limits the carbonation potential of the material. Weathering of slag in a heap could offer an approach with minimal engineering or energy requirements. This investigation of a legacy waste
Table 1. Most Common Slag Mineral Phases Identified in Iron and Steel Making Slags ${ }^{a}$ (from a literature review of 57

\begin{tabular}{|c|c|c|c|}
\hline name & formula & $\begin{array}{c}\text { no. of } \\
\text { citations }\end{array}$ & $\begin{array}{c}\text { cement } \\
\text { notation }\end{array}$ \\
\hline \multicolumn{4}{|c|}{ Silicates } \\
\hline $\begin{array}{l}\text { dicalcium silicate ( } \beta \text { - and } \gamma \text { - } \\
\text { phases) }\end{array}$ & $\mathrm{Ca}_{2} \mathrm{SiO}_{4}$ & 45 & $\mathrm{C}_{2} \mathrm{~S}$ \\
\hline gehlenite & $\mathrm{Ca}_{2} \mathrm{Al}_{2} \mathrm{SiO}_{7}$ & 23 & $\mathrm{C}_{2} \mathrm{~A}_{2} \mathrm{~S}$ \\
\hline tricalcium silicate & $\mathrm{Ca}_{3} \mathrm{SiO}_{5}$ & 21 & $\mathrm{C}_{3} \mathrm{~S}$ \\
\hline merwinite & $\mathrm{Ca}_{3} \mathrm{Mg}\left(\mathrm{SiO}_{4}\right)_{2}$ & 14 & $\mathrm{C}_{3} \mathrm{MS}_{2}$ \\
\hline quartz & $\mathrm{SiO}_{2}$ & 10 & $S$ \\
\hline \multicolumn{3}{|c|}{ Oxides } & $\mathrm{C}_{2} \mathrm{MS}_{2}$ \\
\hline $\begin{array}{l}\text { calcium ferrite (including } \\
\text { srebrodolskite) }\end{array}$ & $\mathrm{Ca}_{2} \mathrm{Fe}_{2} \mathrm{O}_{5} / \mathrm{CaFe}_{2} \mathrm{O}_{4}$ & 26 & $\mathrm{CF}$ \\
\hline wüstite & $\mathrm{FeO}$ & 26 & - \\
\hline magnetite or maghemite & $\mathrm{Fe}_{3} \mathrm{O}_{4} / \gamma-\mathrm{Fe}_{2} \mathrm{O}_{3}$ & 21 & - \\
\hline periclase & $\mathrm{MgO}$ & 18 & M \\
\hline RO phases (mixed oxides) & $\begin{array}{l}\text { various solid } \\
\text { solutions }\end{array}$ & 18 & - \\
\hline lime & $\mathrm{CaO}$ & 18 & $\mathrm{C}$ \\
\hline $\begin{array}{l}\text { calcium aluminum oxides } \\
\text { (including mayenite) }\end{array}$ & $\begin{array}{l}\mathrm{CaAl}_{2} \mathrm{O}_{3} / \mathrm{Ca}_{3} \mathrm{Al}_{2} \mathrm{O}_{6} / \\
\mathrm{Ca}_{12} \mathrm{Al}_{14} \mathrm{O}_{33}\end{array}$ & 11 & $\mathrm{CA}$ \\
\hline hematite & $\mathrm{Fe}_{2} \mathrm{O}_{3}$ & 9 & - \\
\hline \multicolumn{4}{|c|}{ Hydroxides } \\
\hline portlandite & $\begin{array}{l}\mathrm{Ca}(\mathrm{OH})_{2} \\
\text { Carbonates }\end{array}$ & 20 & $\mathrm{CH}$ \\
\hline calcite & $\mathrm{CaCO}_{3}$ & 19 & - \\
\hline
\end{tabular}
articles listed in the Supporting Information)

deposit offers insight into the effectiveness of carbon sequestration of the lowest-cost approach.

\section{MATERIALS AND METHODS}

Study Site. The field site was the former iron and steel works at Consett, County Durham, U.K. (Figure 1). Iron and steel was produced at the site from 1840 until the plant's closure in 1980, and a brief history of the site has been provided by Mayes et al. ${ }^{48}$ As with many other iron producers of that era, ${ }^{49}$ unwanted slag was simply tipped adjacent to the works in large unlined heaps. Following the plant's closure, the heap was reprofiled and capped with topsoil. In September 2017, three boreholes were drilled into the slag material by GeoSonic Drilling Ltd. (Alloa, U.K.) (for site photographs, see Figure S1) across a $60 \mathrm{~m}$ transect. Approximately $1050 \mathrm{~kg}$ of material was removed from the heap, which equates to nearly a $>90 \%$ recovery; i.e., most of the sample was brought to the surface. The boreholes were installed with well screening through the slag material in accordance with BS ISO 5667-22 to allow for solution and gas sampling. At the drilling site, the heap consisted of $\sim 0.5 \mathrm{~m}$ of topsoil overlaying $\sim 21 \mathrm{~m}$ of slag material. Beneath the slag lay $\sim 0.2 \mathrm{~m}$ of a peat-like material, which was assumed to be the original topsoil. Below this, other superficial deposits consisted of a glacial till of clay and sandstone gravel. The locality is underlain by Carboniferous Lower Pennine Coal Measures, with at least four inferred coal seams crossing the site that were exploited in the past. ${ }^{50}$ One month after well installation, the borehole water levels were recorded using a dipmeter (early October 2017). Very little water was encountered in the wells, with one borehole being dry. Pumping of the two wells that contained water at low flow rates $(<1 \mathrm{~L} / \mathrm{min})$ caused the wells to dry within minutes, indicating that there was little water within 


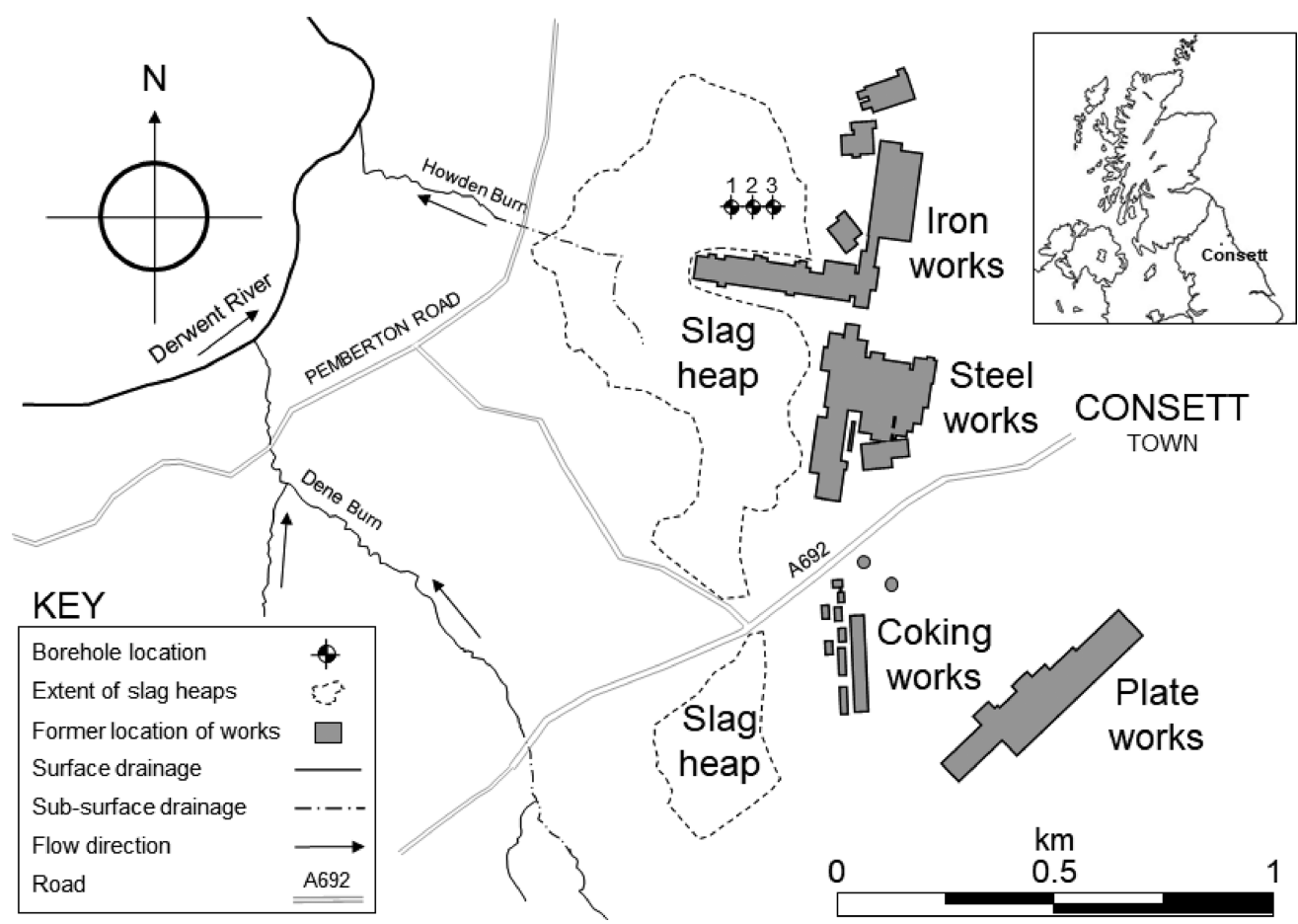

Figure 1. Location map of the former Consett iron works site and borehole locations.

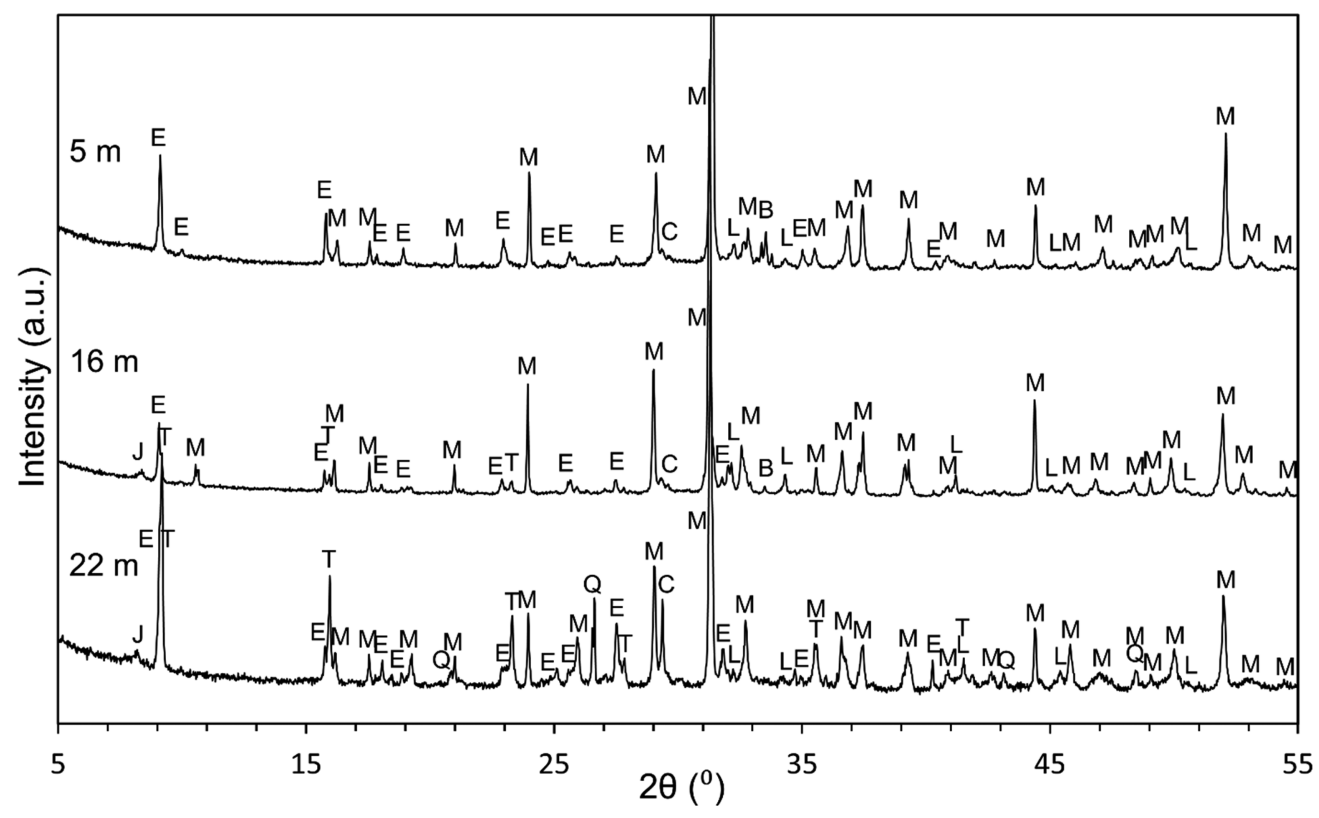

Figure 2. Typical slag diffractograms (from borehole 1) from depths of 5, 16, and $22.5 \mathrm{~m}$, with assigned mineral phases. Key: M, melilite group minerals (gehlenite and åkermanite); E, ettringite; Q quartz; C, calcite; L, larnite; B, brownmillerite; T, thaumasite; J, jenite.

the surrounding material, i.e., no continuous water table. A Hach HQ40D Multimeter was used to measure the $\mathrm{pH}$ of all recovered waters. All waters were highly alkaline, being on average $\mathrm{pH}$ 11.5. Gas monitoring of the wells using a Licor LI820 analyzer during the same field visit revealed that $\mathrm{CO}_{2}$ concentrations were $\sim 85 \mathrm{ppm}$, as compared to $\sim 403 \mathrm{ppm}$ at the surface.

Sample Preparation and Analysis. The three borehole samples were kept within plastic sleeves in wooden drill-core boxes under ambient laboratory conditions until they were required (for photos of the recovered material, see Figure S2). In the laboratory, the plastic sleeves were opened, the boreholes were logged, and samples were taken at consistent depth intervals. The particle size distribution (PSD) was measured by sieve analysis on bulk samples. Selected samples were investigated by X-ray diffraction (XRD), X-ray fluorescence (XRF), acid digestion inductively coupled plasma-optical emission spectroscopy (ICP-OES), total carbon (TC) and total organic carbon (TOC) analysis, and scanning electron microscopy-energy dispersive X-ray spectroscopy (SEMEDS) analysis. Sample analysis methods are detailed in section S1 of the Supporting Information. 
Table 2. Average Elemental Concentrations (wt \% \pm SD) of Slag Samples, Presented with Average Compositional Data for U.S. Slag Data from Proctor et al. ${ }^{54}$

\begin{tabular}{|c|c|c|c|c|c|c|}
\hline & \multirow[b]{2}{*}{$\mathrm{BH} 1$} & \multirow[b]{2}{*}{$\mathrm{BH} 2$} & \multirow[b]{2}{*}{$\mathrm{BH} 3$} & \multicolumn{3}{|c|}{ Proctor et al. ${ }^{54}$ (mean wt $\% \pm S D$ ) } \\
\hline & & & & $\mathrm{BF}$ & BOF & EAF \\
\hline $\mathrm{Na}$ & $0.43 \pm 0.15$ & $0.40 \pm 0.11$ & $0.38 \pm 0.14$ & $\mathrm{NR}^{a}$ & $\mathrm{NR}^{a}$ & $\mathrm{NR}^{a}$ \\
\hline $\mathrm{Ca}$ & $30 \pm 2.4$ & $33 \pm 3.7$ & $34 \pm 4.8$ & $27 \pm 2.8$ & $28 \pm 4.1$ & $25 \pm 3.0$ \\
\hline $\mathrm{Mg}$ & $1.3 \pm 0.59$ & $1.9 \pm 0.59$ & $1.9 \pm 0.056$ & $7.0 \pm 0.93$ & $5.5 \pm 1.1$ & $5.4 \pm 1.7$ \\
\hline $\mathrm{Si}$ & $18 \pm 3.5$ & $16 \pm 1.8$ & $18 \pm 2.1$ & $17 \pm 2.0$ & $6.0 \pm 2.1$ & $7.5 \pm 2.6$ \\
\hline $\mathrm{K}$ & $0.30 \pm 0.093$ & $0.26 \pm 0.063$ & $0.26 \pm 0.051$ & $\mathrm{NR}^{a}$ & $\mathrm{NR}^{a}$ & $\mathrm{NR}^{a}$ \\
\hline $\mathrm{Fe}$ & $4.0 \pm 5.6$ & $1.4 \pm 2.0$ & $0.86 \pm 0.48$ & $1.7 \pm 3.0$ & $18 \pm 4.0$ & $19 \pm 6.5$ \\
\hline $\mathrm{Al}$ & $5.3 \pm 0.67$ & $5.8 \pm 0.89$ & $6.3 \pm 0.42$ & $4.1 \pm 0.57$ & $2.4 \pm 3.0$ & $3.5 \pm 1.2$ \\
\hline $\mathrm{Mn}$ & $0.57 \pm 0.30$ & $0.58 \pm 0.24$ & $0.61 \pm 0.084$ & $0.55 \pm 0.48$ & $3.3 \pm 1.2$ & $3.9 \pm 0.77$ \\
\hline$S$ & $1.1 \pm 0.25$ & $1.1 \pm 0.46$ & $1.5 \pm 0.36$ & $1.0 \pm 0.31$ & $0.11 \pm 0.11$ & $0.19 \pm 0.071$ \\
\hline $\mathrm{Ba}$ & $0.26 \pm 0.23$ & $0.14 \pm 0.045$ & $0.24 \pm 0.12$ & $0.027 \pm 0.0067$ & $0.0075 \pm 0.0062$ & $0.056 \pm 0.029$ \\
\hline $\mathrm{Sr}$ & $0.13 \pm 0.024$ & $0.16 \pm 0.017$ & $0.16 \pm 0.024$ & $\mathrm{NR}^{a}$ & $\mathrm{NR}^{a}$ & $\mathrm{NR}^{a}$ \\
\hline $\mathrm{Ti}$ & $0.15 \pm 0.014$ & $0.16 \pm 0.022$ & $0.17 \pm 0.016$ & $\mathrm{ND}^{b}$ & $0.00072 \pm 0.00057$ & $0.0011 \pm 0.00075$ \\
\hline $\mathrm{Zn}$ & $0.0082 \pm 0.0015$ & $0.0041 \pm 0.0011$ & $0.0026 \pm 0.00053$ & $0.0020 \pm 0.0037$ & $0.0046 \pm 0.0039$ & $0.017 \pm 0.015$ \\
\hline $\mathrm{P}$ & $0.0057 \pm 0.0040$ & $0.0029 \pm 0.0018$ & $0.0046 \pm 0.00070$ & $0.022 \pm 0.032$ & $0.32 \pm 0.13$ & $0.18 \pm 0.094$ \\
\hline
\end{tabular}

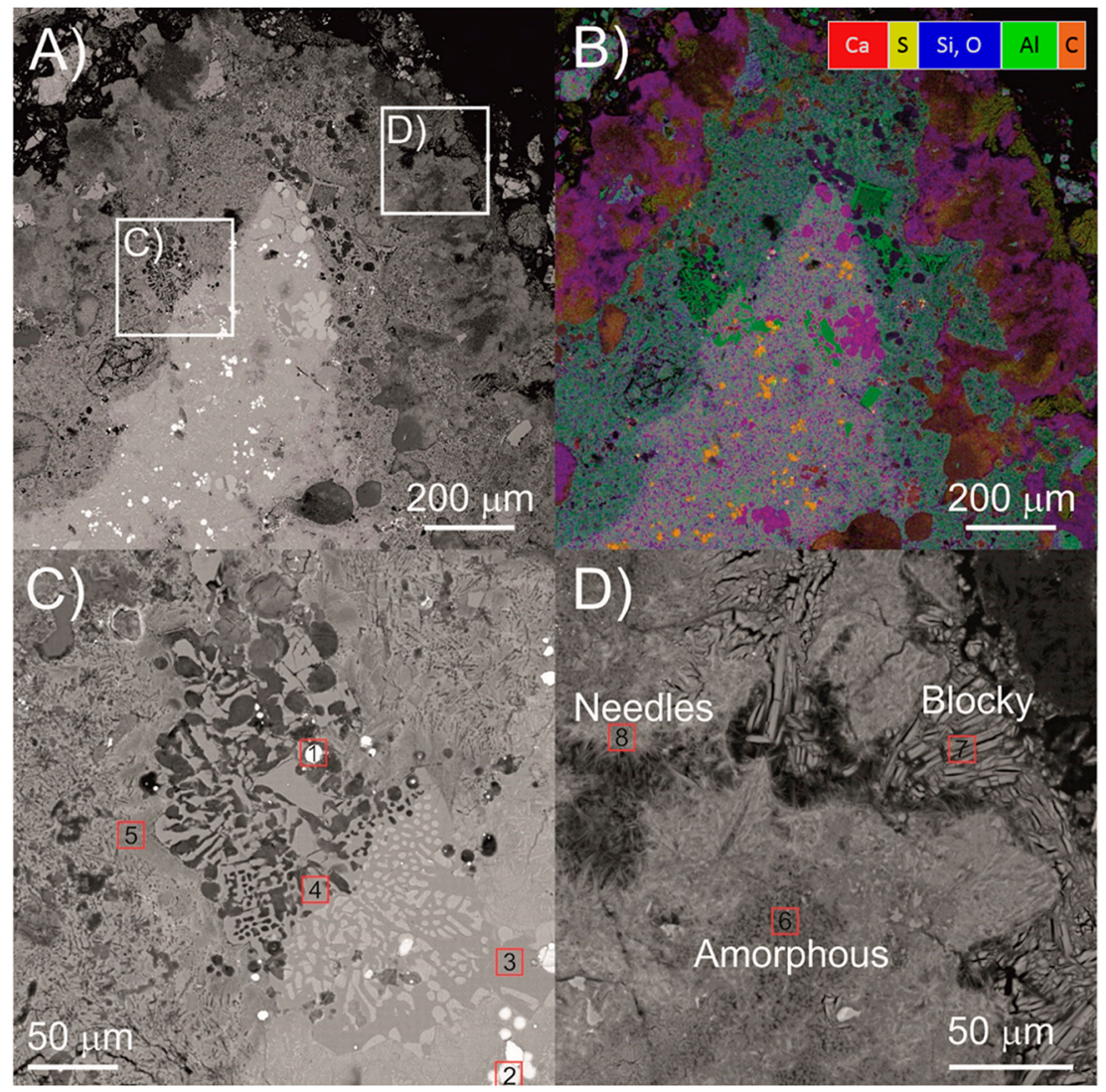

Figure 3. (A) Low-resolution backscatter electron image and (B) false color merged $\mathrm{Ca}-\mathrm{SiO}-\mathrm{S}-\mathrm{Al}-\mathrm{C}$ SEM-EDS map showing the alteration rind present in a sample recovered from $\mathrm{BH} 1$ (depth of $16 \mathrm{~m}$ ). (C) High-resolution backscatter electron image showing the development of porosity at the inner alteration front. (D) High-resolution backscatter electron image showing fabric variation in three precipitated phases present in the altered layer. The positions of images $\mathrm{C}$ and $\mathrm{D}$ are shown as white squares in panel $\mathrm{A}$. The red squares in panels $\mathrm{C}$ and $\mathrm{D}$ show locations representative of distinct compositions found in EDS spot analysis (Table S6).

\section{RESULTS AND DISCUSSION}

Slag Composition. XRD analysis of the samples revealed many overlapping spectra (Figure 2), indicating that there were a number of identifiable crystalline phases present in the slag material. ${ }^{28}$

Of note, little variance was observed within the slag heap (for additional diffractograms, see Figure S3), and the slag material can be generally characterized as "Ca silicate-rich", dominated by melilite group minerals [gehlenite $\left(\mathrm{Ca}_{2} \mathrm{Al}_{2} \mathrm{SiO}_{7}\right)$ and åkermanite $\left.\left(\mathrm{Ca}_{2} \mathrm{MgSi}_{2} \mathrm{O}_{7}\right)\right]$. These have been observed to be the first slag phases that crystallize. ${ }^{51}$ Minor mineral phases that were identified included larnite and brownmillerite $\left[\mathrm{Ca}_{2}(\mathrm{AlFe})_{2} \mathrm{O}_{5}\right]$ and minor secondary phases of calcite $\left(\mathrm{CaCO}_{3}\right)$, jennite $\left[\mathrm{Ca}_{9} \mathrm{Si}_{6} \mathrm{O}_{18}(\mathrm{OH})_{6} \cdot 8 \mathrm{H}_{2} \mathrm{O}\right]$, and ettringite 
$\left[\mathrm{Ca}_{6} \mathrm{Al}_{2}\left(\mathrm{SO}_{4}\right)_{3}(\mathrm{OH})_{12} \cdot 26 \mathrm{H}_{2} \mathrm{O}\right]$. Quartz $\left(\mathrm{SiO}_{2}\right)$ would not have precipitated from the slag itself and is most likely present from soil or sediment mixing. The presence of calcite indicates that some carbonation reactions have occurred after the slag was created, but it is not possible to state when these reactions took place, before or after burial. Fayalite $\left(\mathrm{Fe}_{2} \mathrm{SiO}_{4}\right)$ was also encountered, immediately beneath the surface, close to the position of the former works in borehole 3 (see Figure 1). Due to its location, this was considered unutilized slag conditioner ${ }^{52,53}$ that had been buried after the steelworks had closed.

The most abundant elements in the slag material, identified using acid digestion and ICP-OES, were $\mathrm{Ca}$, at an average concentration of $33 \mathrm{wt} \%$, and $\mathrm{Si}$, at $18 \mathrm{wt} \%$ (see Table 2 for total extraction ICP-OES data and Table S4).

Due to the low $\mathrm{Mg}$ concentrations, it is probable that gehlenite, rather than åkermanite, is the predominant melilite phase and that lime/calcitic limestone $\left(\mathrm{CaCO}_{3}\right)$ was used as a flux, rather than dolomitic limestone ${ }^{55}$ [the Consett Iron Company purchased some quarries at Stanhope in 1842 to supply limestone for the works ${ }^{50}$ (now closed), which were located in the Great Limestone Member of the Alston Formation of Carboniferous Age].

Matching the lack of variation in the mineralogical composition, the elemental composition of the material was also relatively homogeneous (see Figures S4 and S5). Differences in elemental concentrations are apparent between the ICP-OES and XRF data, most notably with $\mathrm{Ca}, \mathrm{Si}$, and $\mathrm{Fe}$. Considering the analysis of $\mathrm{Ca}$, for example, in the STSD-1 calibration standard material, the XRF instrument (Table S2) "read high" (+9.6\%), possibly due to matrix effects that are common with slags, ${ }^{56}$ while the ICP-OES instrument (Table S4) "read low" (-2.7\%), possibly due to incomplete digestion of the mineral sample. These variances can account for the differences in reported concentrations between the two methods employed, although the ICP-OES data were determined to be more accurate than the XRF data (section S1 of the Supporting Information).

The borehole locations are close to the site of the former iron works (Figure 1), ${ }^{57}$ which employed blast furnaces to liberate iron from the ore. ${ }^{48,50}$ This fact, along with the high Ca and Si content and the relatively high $\mathrm{S}$ and low metal ( $\mathrm{Fe}, \mathrm{Mn}$, and $\mathrm{V}$ ) content, points to the material being BF slag (Table 2). BF slags are produced when iron ore is reduced with $\mathrm{C}$. This leads to enrichment of the slag with $S$ and the reduction of metals in the molten iron. ${ }^{14,23,28,54,58,59}$ The primary minerals (i.e., melilite phases, larnite, brownmillerite, and quartz) are also consistent with air-cooled BF slag compositions. ${ }^{51,58}$ The presence of several hydrated phases $\left\{\right.$ e.g., ettringite and thaumasite $\left[\mathrm{Ca}_{3} \mathrm{Si}\right.$ $\left.\left.(\mathrm{OH})_{6}\left(\mathrm{CO}_{3}\right)\left(\mathrm{SO}_{4}\right) \cdot 12 \mathrm{H}_{2} \mathrm{O}\right]\right\}$ and calcite is also consistent with partial hydration and carbonation of the $\mathrm{BF}$ slag since production.

Electron microscopy imaging revealed an interlocking matrix of slag phases, and SEM-EDS analysis (Figure S6 and Table S5) produced compositions that roughly match those of minerals already identified by XRD (although due to overlapping phases in the samples, "pure" examples of the minerals were not identified). Elemental maps of this sample are presented in Figure S7.

Generally, samples had experienced little carbonation. There was, however, considerable variation in the extent of alteration rinds observed between samples, which varied in thickness from 0 to $5 \mathrm{~mm}$. In one sample, three separate regions could be observed (Figure 3 and Table S6), consisting of a core region containing primary slag phases; a Ca-, Si-, and S-depleted inner alteration layer where the most reactive phases (e.g., larnite and an unidentified $\mathrm{Ca}-\mathrm{S}$ phase) were absent; and an outer layer composed of secondary phases [e.g., ettringite, thaumasite, and calcium-silicate-hydrate ( $\mathrm{CSH})]$ that were also found in vesicles and cracks. The altered region appears darker in the BSE images, indicating a lower average density of the materials found in this layer. In high-resolution images (Figure 3C), the darker areas in the top left of the image represent pore spaces in the sample that are absent in the core region. The boundary between the core and inner layer may represent a hydration front marking the limit of diffusion of water into the samples. The outer boundary between the inner and outer layers may represent the original slag surface that has now been coated with secondary precipitates.

Carbon Budget and Storage Potential. $\mathrm{A} \mathrm{CO}_{2}$ capture potential can be calculated for the slag material and the total heap on the basis of the assumption that (a) the slag undergoes further carbonation until all amenable elements are expended and (b) all of the $\mathrm{C}$ is fixed from inorganic sources, i.e., from atmospheric/dissolved $\mathrm{CO}_{2}$. Previous studies have highlighted the prevalence of atmospheric carbon sources over lithogenic sources in "off-site" secondary carbonate deposits at this site. ${ }^{48}$

From previous work, it was inferred that the slag heap at Consett is approximately $16 \mathrm{Mm}^{3}$ in volume. ${ }^{48} \mathrm{~A}$ dry bulk density value of $1.79 \mathrm{~g} / \mathrm{cm}^{3}$ was determined from analysis of 20 samples, which equates to $29 \mathrm{Mt}$ of emplaced slag at the study site. Carbon dioxide capture potentials by both direct carbonation $\left(C_{\text {pot }}\right)$ and enhanced weathering $\left(E_{\text {pot }}\right)$ were calculated from the ICP-OES data, using a modified version of the Steinour formula (eqs 5 and 6). ${ }^{25}$

$$
\begin{aligned}
C_{\text {pot }}= & \frac{M_{\mathrm{CO}_{2}}}{100}\left(\alpha \frac{\mathrm{CaO}}{M_{\mathrm{CaO}}}+\beta \frac{\mathrm{MgO}}{M_{\mathrm{MgO}}}+\gamma \frac{\mathrm{SO}_{2}}{M_{\mathrm{SO}_{2}}}+\delta \frac{\mathrm{P}_{2} \mathrm{O}_{5}}{M_{\mathrm{P}_{2} \mathrm{O}_{5}}}\right) \\
& \times 10^{3} \\
E_{\text {pot }}= & \frac{M_{\mathrm{CO}_{2}}}{100}\left(\alpha \frac{\mathrm{CaO}}{M_{\mathrm{CaO}}}+\beta \frac{\mathrm{MgO}}{M_{\mathrm{MgO}}}+\varepsilon \frac{\mathrm{Na}_{2} \mathrm{O}}{M_{\mathrm{Na}_{2} \mathrm{O}}}+\theta \frac{\mathrm{K}_{2} \mathrm{O}}{M_{\mathrm{K}_{2} \mathrm{O}}}\right. \\
& \left.+\gamma \frac{\mathrm{SO}_{2}}{M_{\mathrm{SO}_{2}}}+\delta \frac{\mathrm{P}_{2} \mathrm{O}_{5}}{M_{\mathrm{P}_{2} \mathrm{O}_{5}}}\right) \times 10^{3} \eta
\end{aligned}
$$

where $\mathrm{CaO}, \mathrm{MgO}, \mathrm{SO}_{3}, \mathrm{P}_{2} \mathrm{O}_{5}, \mathrm{Na}_{2} \mathrm{O}$, and $\mathrm{K}_{2} \mathrm{O}$ are the elemental concentrations of $\mathrm{Ca}, \mathrm{Mg}, \mathrm{S}, \mathrm{P}, \mathrm{Na}$, and $\mathrm{K}$ expressed as oxides, respectively, and $M_{\mathrm{x}}$ is the molecular mass of those oxides. Coefficients $\alpha, \beta, \gamma, \delta, \varepsilon$, and $\theta$ consider the relative contribution of each oxide. $\eta$ is the molar ratio of $\mathrm{CO}_{2}$ to the divalent cation sequestered during enhanced weathering (see below).

For direct carbonation, the molar ratio of the divalent cation to atmospheric $\mathrm{CO}_{2}$ is 1 (eqs 1 and 2). Enhanced weathering (eqs 3 and 4) has the capacity to take up two $\mathrm{CO}_{2}$ molecules from the atmosphere, i.e., a doubling of the molar ratio of the divalent cation to atmospheric $\mathrm{CO}_{2}$ over that of direct carbonation. In this scenario, the carbonate formed in solution does not precipitate but through aqueous transport reaches the ocean. However, the distribution of carbonate in the ocean is determined by carbonate equilibrium reactions, e.g., eq 7 :

$$
\begin{aligned}
\mathrm{H}^{+}+\mathrm{HCO}_{3}^{-}(\mathrm{aq}) & \leftrightarrows 2 \mathrm{H}^{+}+\mathrm{CO}_{3}{ }^{2-}{ }_{(\mathrm{aq})} \\
& \leftrightarrows \mathrm{CO}_{2(\mathrm{~g})}+\mathrm{H}_{2} \mathrm{O}_{(\mathrm{l})}
\end{aligned}
$$


This reaction quickly finds equilibrium, and as such, an increase in the amount of bicarbonate from enhanced weathering will ultimately promote the degassing of some $\mathrm{CO}_{2}$ from the seawater. Due to this degassing, a more realistic molar ratio of $\mathrm{CO}_{2}$ to divalent cations for enhanced weathering is between 1.4 and 1.7. ${ }^{19}$

Assuming that the samples are representative of heap material across the site, an average fully carbonated slag sample would have a carbon concentration of $11.7 \%$. From TC and TOC analysis, it was determined that there was no organic carbon and that the average TC concentration of the slag was $0.42 \%$ $( \pm 1.0 \%)$ (see Figure S5 for sample C concentrations). This equates to $3.6 \%$ of the $\mathrm{TC}$ capture potential having been expended (with a variance of $0-12.1 \%$ ).

Table 3 suggests that the $\mathrm{CO}_{2}$ capture potential for the slag material is far from fully realized. Mayes et al. ${ }^{48}$ estimated that

Table 3. Calculated $\mathrm{CO}_{2}$ Capture Potentials Using a Modification of the Steinour Equation for Material from the Consett Slag Heap Based on Total Carbonation of Amenable Ions

$\begin{array}{cccc} & & \begin{array}{c}\mathrm{CO}_{2} \text { capture potential } / \mathrm{kg} \text { of } \\ \text { slag }\left(\mathrm{kg} \text { of } \mathrm{CO}_{2} / \mathrm{t}\right)\end{array} & \begin{array}{c}\text { total heap } \mathrm{CO}_{2} \\ \text { capture potential }(\mathrm{Mt})\end{array} \\ \begin{array}{c}\text { direct } \\ \text { carbonation } \\ \text { enhanced } \\ \text { weathering }\end{array} & \begin{array}{c}C_{\text {pot }} \\ E_{\text {pot }}\end{array} & 296-337 & 8.5-9.7 \\ & \begin{array}{c}E_{\text {pot }} \\ 1.7\end{array} & 422-481 & 12.1-13.8 \\ & & 513-584 & 14.7-16.7 \\ \end{array}$

$\sim 8.5 \mathrm{t}$ of $\mathrm{Ca}$ is leached from the heap every year, which equates to $\sim 850 \mathrm{t}$ since the steelworks began producing slag, which in turn suggests that $1176-1428 \mathrm{t}$ of $\mathrm{CO}_{2}$ has been captured. The current work suggests that there is a capture potential of 8.5-9.7 $\mathrm{Mt}$ of $\mathrm{CO}_{2}$ in the Consett heap via direct carbonation and 12.116.7 $\mathrm{Mt}$ of $\mathrm{CO}_{2}$ via enhanced weathering, and as such, the heap represents a very large, underutilized carbon sink.

Limits on Carbonation. Physical and Chemical Properties of the Slag. While the total elemental composition of a material provides a theoretical upper limit on carbon sequestration potential, the influences of slag mineralogy also need to be considered to determine if this limit is achievable. Mineral carbonation is controlled by the availability of $\mathrm{Ca}$ and $\mathrm{CO}_{2}$ to form carbonate or bicarbonate complexes and precipitates. ${ }^{48}$ As such, diffusion-limited transport of Ca ions from the interior dissolution front (leading to a silica-enriched region, as seen in Figure 3) to the exterior fluid-solid interface is crucial. $^{60}$ Therefore, mineralogy plays a major role in carbonation reactions, ${ }^{12,26,36,38}$ as it controls dissolution, ${ }^{61,62}$ and mineral dissolution has been reported as the rate-limiting step. $^{12,63}$

At Consett, melilites were identified as the major mineral phase (Figure 2). Baciocchi et al. ${ }^{64}$ and others ${ }^{65}$ have observed the unreactive nature of melilites, which did not significantly react in a $24 \mathrm{~h}$ carbonation experiment, even a fine fraction $(<150 \mu \mathrm{m})$, at elevated temperatures $\left(>70{ }^{\circ} \mathrm{C}\right)$ with pure $\mathrm{CO}_{2}$ streams. This infers that reaching the full sequestration potential of the heap is unfeasible due to $\mathrm{Ca}^{2+}$ residing in slow-reacting minerals. The emplacement conditions of the slag further hinder sequestration. Hydrolysis of slag minerals leads to the formation of hydroxyl $\left(\mathrm{OH}^{-}\right)$ions, ${ }^{66}$ which are responsible for the elevated $\mathrm{pH}$ (11.5) in the heap. Under such alkaline conditions, the dissolution rate of slag minerals, including melilites, is slow, ${ }^{67-69}$ compared to neutral or acidic conditions. Even minerals that are reactive under ambient weathering conditions (e.g., larnite, ${ }^{70}$ identified as a minor slag phase at Consett) have moderate dissolution rates at high $\mathrm{pH}$.

$\mathrm{CaS}$ phases are commonly found in blast furnace slags, ${ }^{58}$ occurring as inclusions in melilites. A Ca- and S-containing compound was identified in the slag by SEM-EDS [ $\mathrm{CaS}$ " phase (Table S6)]. No crystalline CaS phases (e.g., oldhamite) were detected by XRD; therefore, this may be amorphous $\mathrm{CaS}$, which has been previously reported to occur in BF slag. ${ }^{71}$ This phase represents a potential source of leachable sulfate in the slag, which may explain the precipitation of very low solubility, hydrated calcium-( $\mathrm{Al}, \mathrm{Si}$ )-sulfate phases (e.g., ettringite and thaumasite, ${ }^{38,72}$ shown in Figures 2 and 3). These phases provided a sink for $\mathrm{Ca}^{2+}$ ions that otherwise could have been utilized in carbonation reactions ${ }^{16}$ (i.e., the $\mathrm{Ca}: \mathrm{CO}_{3}$ ratio in ideal thaumasite is $3: 1$, as compared to $1: 1$ in calcite). These lowsolubility phases, as well as phases such as calcite (also observed in Figure 2), can hinder dissolution by pore clogging and/or surface coating, ${ }^{12,22,26,34}$ which limits the access of fluid to the mineral surface. ${ }^{73}$ Due to their formation, further weathering becomes controlled by the dissolution-reprecipitation of these secondary phases at interfacial surfaces ${ }^{70,74,75}$ rather than dissolution of primary slag silicates in particle cores, a process that influences natural silicate weathering. ${ }^{73}$ Our observations from within the Consett slag heap suggest that primary mineral dissolution and secondary mineral precipitation likely play a substantial limiting role in slag carbonation potential, although with limited sampling, it is not possible to quantify the influence or extent of this phenomenon in the Consett heap.

With regard to physical properties, averaged particle size distribution curves for the three boreholes are presented in Figure S8. The size of particles influences both the reactive surface area and the transport of reactants (gas and dissolved gas) and so has an important influence on the dissolution behavior of a slag heap. ${ }^{12,63,72,76}$ A comparison here can be drawn with mineral heap leaching. Experimental evidence suggests that leaching of large particles $(12-25 \mathrm{~mm})$ occurs only at the surface and in subsurface regions that can be accessed from the surface by cracks and pores. ${ }^{77}$ This leads to a trade-off between expending energy crushing material and the slow rate and limited extent of leaching large particles. In the samples recovered from Consett, $\sim 80 \%$ of the material was $>4 \mathrm{~mm}$ in diameter and $>50 \%$ of the material $>10 \mathrm{~mm}$ in diameter, which constrains a considerable fraction of the $\mathrm{Ca}^{2+}$ ions as unavailable for carbonation. When considering $<150 \mu \mathrm{m}$ slags ${ }^{38,64,65}$ in "active" reactor studies did not reach full carbonation, the material at the Consett site was far from ideal for complete conversion to carbonates under atmospheric conditions.

Slag Emplacement Conditions. On a return visit to the study site in September 2017, $\mathrm{CO}_{2}$ concentrations in the three boreholes were low $(\sim 85 \mathrm{ppm})$ relative to ambient $\mathrm{CO}_{2}$ concentrations $(\sim 403 \mathrm{ppm})$. It is probable that $\mathrm{CO}_{2}$ recharge is currently limiting, being slower than the rate of $\mathrm{CO}_{2}$ consumption via aqueous dissolution or mineral incorporation. Stewart et al. ${ }^{75}$ reported that when slag weathers with limited $\mathrm{CO}_{2}$, secondary hydrated phases (e.g., $\mathrm{CSH}$ ) are formed at mineral edges. These were observed via SEM analysis (Figure 3 ), supporting the idea that $\mathrm{CO}_{2}$ is limited in the slag heap.

Even in the presence of $\mathrm{CO}_{2}$, experimental studies have shown that water plays a key role in carbonation. ${ }^{78}$ Direct dry $\mathrm{Ca} / \mathrm{Mg}$ silicate carbonation was shown to be insignificant, even at elevated pressures, ${ }^{79}$ and the carbonation efficiencies of slag 
material improved with an increase in liquid:solid ratios ${ }^{63,80-82}$ (as well as an increase in the concentration of dissolved $\left.\mathrm{CO}_{2}\right)^{12}$ Water levels were low or dry in the boreholes during the site visit in early October, despite Consett having a Köppen climate classification of "oceanic" (>800 $\mathrm{mm}$ of rain annually), and September being on average one of the wettest months of the year. ${ }^{83}$ Unfortunately, the moisture content of the recovered drill core material could be not be assessed as water was used as a drilling fluid, but a resistivity survey conducted by Mayes et al. ${ }^{48}$ indicated that the groundwater distribution in the slag heap is heterogeneous and that solute-rich waters are likely to be present in some areas. This highlights a limitation of this study and the fact that some assumptions have had to be made due to sampling locations. However, in the area sampled, water (and $\mathrm{CO}_{2}$ ) ingress appears to be restricted due to capping of the slag with a clayey topsoil, reducing water/gas ingress, and therefore preventing the carbonation of the slag material. It is also possible that weathering has caused localized expansion in slag volume, ${ }^{84}$ reducing porosity and limiting water and $\mathrm{CO}_{2}$ ingress, but this is purely speculative.

Further to the west of the study site, the Howden Burn stream emerges from the toe of the slag heap (see Figure 1). This water course had become buried as the heap was expanded in the late 19th Century. A long-term ( 40 year) study of these waters reported that they continue to be highly alkaline and loaded with metals, ${ }^{48,85}$ which is consistent with observations made during SEM analysis. The secondary phases, e.g., CSH, observed in Figure 3 were relatively Ca-rich [Ca:Si ratio of $>2$ (see Table S6)] and are predicted to equilibrate with water to produce leachates with high $\mathrm{pH}$ and $\mathrm{Ca}$ concentrations and low $\mathrm{Si}$ concentrations. ${ }^{86}$ Again, this is based on limited sample analysis and may not be representative of the entire heap. However, the alkaline drainage waters indicate that dissolution is occurring where water interacts with the slag. ${ }^{70,87}$ Carbon sequestration reactions have been reported to occur within the lower reaches of the Howden Burn where atmospheric $\mathrm{CO}_{2}$ has reacted with the emergent drainage waters to precipitate carbonate as calcite pans. ${ }^{48,85}$ However, these deposits represent a very small $\mathrm{CO}_{2}$ capture percentage when considering the large volume of silicate minerals remaining in the slag heap. ${ }^{48}$

Implications. While managed, engineered approaches have reported impressive results in the conversion of silicate mineral wastes to carbonates, ${ }^{12,15,22}$ here we have shown that a passive approach has led to very limited mineral carbonation. The mineralogy, particle size, and emplacement conditions of the slag are identified as factors limiting carbonation. When the $\mathrm{CO}_{2}$ sequestration potential of a slag heap is determined using a finite number of boreholes, assumptions must be made about the physical and chemical characteristics of the material. However, the lateral homogeneity and horizontal homogeneity of samples within the $60 \mathrm{~m}$ transect (see Figures S3 and S4) provide a good level of confidence in the extrapolations that have been made in this study.

While there is extensive evidence of atmospheric $\mathrm{CO}_{2}$ sequestration at the site and high extents of reaction have been reported from controlled well-mixed experiments, ${ }^{45-47}$ this study highlights the importance of developing slag management practices if carbon draw-down is to be optimized. The chemical composition of slags is dependent upon both the raw materials used and the iron and steel making process, ${ }^{68,88,89}$ but these slags can be manipulated postfurnace to enhance $\mathrm{CO}_{2}$ sequestration properties. For example, if immediately quenched, tricalcium silicates, e.g., merwinite $\left[\mathrm{Ca}_{3} \mathrm{Mg}\left(\mathrm{SiO}_{4}\right)_{2}\right]$, rather than melilites would be the dominant mineralogical phase of $\mathrm{BF}$ slag. ${ }^{58,90}$ Tricalcium silicates are more suited to carbonation as they are more amenable to dissolution than either gehlenite or åkermanite ${ }^{67}$ and are easily hydrated. ${ }^{91}$ In addition, rapid quenching can produce a granular ${ }^{92,93}$ slag with a larger surface area (and hence greater reactivity). Therefore, fast quenched BF slag will carbonate more rapidly and to a greater extent than aircooled, crystalline BF slags. However, when rapidly cooled, ground, granulated blast furnace slag has a high value in the modern economy as a partial replacement for Portland cement in concrete production, ${ }^{94,95}$ which also displaces $\mathrm{CO}_{2}$ emissions from cement clinker manufacturing. ${ }^{92,96}$ An alternative could be to target BOF and EAF (rather than BF) slags for carbon sequestration, which are dominated by more reactive silicates than melilites, including merwinite and larnite, ${ }^{28,97}$ and are more likely at present to be landfilled than BF slag. ${ }^{90,98}$

When considering emplacement of the slag material, creating shallower piles without topsoil cover would aid water and gas movement and management (e.g., similar to windrow oxidation of organic wastes). ${ }^{99,100}$ Water is especially important, acting as both a reactant (when carrying dissolved $\mathrm{CO}_{2}$ or promoting hydration/dissolution reactions) and a transport medium. More rapid flushing rates could prevent the formation of poorly soluble surface layers as observed in this work (Figure 3), by preventing the supersaturation of precipitating phases at mineral surfaces. $^{73}$ Preventing precipitation would also promote bicarbonate over carbonate formation, thus sequestering a greater ratio of $\mathrm{CO}_{2}$ to $\mathrm{Ca}^{2+} \cdot{ }^{19}$ In addition, active management of water in the heap not only may accelerate carbonation reactions but also could aid in the management of alkaline leachates that slag heaps produce, which can last decades. ${ }^{101,102}$

It is noted that treatment (excavation, comminution, and reprofiling) of any legacy heap near urban areas may be difficult and/or unwelcome due to the aesthetics of such an industrial artifact and the established afteruses on the surface (e.g., the residential and commercial developments and established parkland on the Consett heap). However, the careful production and treatment of the 420-610 Mt of slag produced annually ${ }^{23-25}$ to generate " $\mathrm{CO}_{2}$ amenable" material could offset some of the industry's considerable $\mathrm{CO}_{2}$ footprint and aid in future removal of global greenhouse gas from the atmosphere.

\section{ASSOCIATED CONTENT}

\section{S Supporting Information}

The Supporting Information is available free of charge on the ACS Publications website at DOI: 10.1021/acs.est.9b01265.

Explanation of sample analyses, tables showing common slag minerals and physicochemical slag characteristics, and figures of photographs of field work and sample material, SEM images, and physicochemical slag characteristics (PDF)

\section{AUTHOR INFORMATION}

\section{Corresponding Author}

*E-mail: PullinH2@cardiff.ac.uk.

ORCID

Huw Pullin: 0000-0002-6369-3532

Andrew W. Bray: 0000-0001-5399-6647

Ian T. Burke: 0000-0002-0484-568X

William M. Mayes: 0000-0002-1864-9057 


\section{Notes}

The authors declare no competing financial interest.

\section{ACKNOWLEDGMENTS}

The authors thank Anthony Oldroyd and Jeffrey Rowlands (Cardiff University) for help with XRD analysis and ICP analysis, respectively, and Lesley Neve and Duncan Hedges (University of Leeds) for help with XRF and SEM analysis, respectively. The authors also thank Richard Davies (Rhondda Geotechnical Services), GeoSonic Drilling, Durham County Council, and Mark Short (Dysart Group/Project Genesis) for assistance during sample collection. H.P., D.D.M., D.J.S., and P.R. acknowledge funding as part of the UK Greenhouse Gas Removal Programme with from the Natural Environment Research Council (NERC), the Engineering and Physical Sciences Research Council (EPSRC), Economic \& Social Research Council (ESRC), and the Department for Business, Energy \& Industrial Strategy (BEIS), under Grant NE/ P019943/1. I.T.B., A.W.B., and W.M.M. acknowledge support by NERC Grants NE/L01405X/1 and NE/L014211/1. The authors thank the four anonymous reviewers whose comments significantly improved the manuscript.

\section{REFERENCES}

(1) Monastersky, R. Global carbon dioxide levels near worrisome milestone: concentrations of greenhouse gas will soon surpass 400 parts per million at sentinel spot. Nature 2013, 497 (7447), 13.

(2) Climate Change 2014: Synthesis Report. IPCC: Geneva, 2014; p 151.

(3) Summary for Policymakers: Global warming of $1.5^{\circ} \mathrm{C}$. An IPCC Special Report on the impacts of global warming of $1.5^{\circ} \mathrm{C}$ above preindustrial levels. World Meteorological Organization: Geneva, 2018.

(4) The Royal Society and the Royal Academy of Engineering. Greenhouse gas removal. 2018.

(5) Negatice Emissions Technolgies and Reliable Sequestration: A Research Agenda. The National Academy of Sciences: Washington, DC, 2018.

(6) European Academies Science Advisory Council. Negative emission technologies: What role in meeting Paris Agreement targets?; European Academies: Teutschenthal, Germany, 2018.

(7) Keith, D. W.; Holmes, G.; St. Angelo, D.; Heidel, K. A Process for Capturing CO2 from the Atmosphere. Joule 2018, 2 (8), 1573-1594.

(8) Fajardy, M.; Chiquier, S.; Mac Dowell, N. Investigating the BECCS resource nexus: delivering sustainable negative emissions. Energy Environ. Sci. 2018, 11 (12), 3408-3430.

(9) Sanna, A.; Uibu, M.; Caramanna, G.; Kuusik, R.; Maroto-Valer, M. M. A review of mineral carbonation technologies to sequester $\mathrm{CO} 2$. Chem. Soc. Rev. 2014, 43 (23), 8049-8080.

(10) Seifritz, W. CO2 disposal by means of silicates. Nature 1990, 345, 486.

(11) Lackner, K. S.; Wendt, C. H.; Butt, D. P.; Joyce, E. L.; Sharp, D. H. Carbon dioxide disposal in carbonate minerals. Energy 1995, 20 (11), 1153-1170.

(12) Huijgen, W. J. J.; Comans, R. N. J. Mineral CO2 Sequestration by Steel Slag Carbonation. Environ. Sci. Technol. 2005, 39 (24), 96769682.

(13) Huijgen, W. J. J.; Comans, R. N. J. Carbonation of Steel Slag for CO2 Sequestration: Leaching of Products and Reaction Mechanisms. Environ. Sci. Technol. 2006, 40 (8), 2790-2796.

(14) Eloneva, S.; Teir, S.; Salminen, J.; Fogelholm, C.; Zevenhoven, R. Fixation of $\mathrm{CO} 2$ by Carbonating Calcium Derived from Blast Furnace Slag. Energy 2008, 33 (9), 1461-1467.

(15) Pan, S. Y.; Chang, E. E.; Chiang, P. C. CO2 Capture by Accelerated Carbonation of Alkaline Wastes: A Review on Its Principles and Applications. Aerosol Air Qual. Res. 2012, 12 (12), 770-791.
(16) Béarat, H.; McKelvy, M. J.; Chizmeshya, A. V. G.; Gormley, D.; Nunez, R.; Carpenter, R. W.; Squires, K.; Wolf, G. H. Carbon Sequestration via Aqueous Olivine Mineral Carbonation: Role of Passivating Layer Formation. Environ. Sci. Technol. 2006, 40 (15), 4802-4808.

(17) Newall, P. S.; Clarke, S. J.; Haywood, H. M.; Scholes, H.; Clarke, N. R.; King, P. A. $\mathrm{CO}_{2}$ storage as carbonate; International Energy Agency: Paris, 2000.

(18) Morgan, B.; Wilson, S. A.; Madsen, I. C.; Gozukara, Y. M.; Habsuda, J. Increased thermal stability of nesquehonite (MgCO3. $3 \mathrm{H} 2 \mathrm{O}$ ) in the presence of humidity and $\mathrm{CO} 2$ : Implications for lowtemperature CO2 storage. Int. J. Greenhouse Gas Control 2015, 39, 366376.

(19) Renforth, P.; Henderson, G. Assessing ocean alkalinity for carbon sequestration. Rev. Geophys. 2017, 55 (3), 636-674.

(20) Steel Statistical Yearbook 2017; World Steel Association: Brussels, 2017.

(21) Morfeldt, J.; Nijs, W.; Silveira, S. The impact of climate targets on future steel production - an analysis based on a global energy system model. J. Cleaner Prod. 2015, 103, 469-482.

(22) Polettini, A.; Pomi, R.; Stramazzo, A. CO2 sequestration through aqueous accelerated carbonation of BOF slag: A factorial study of parameters effects. J. Environ. Manage. 2016, 167, 185-195.

(23) European Slag Association (EUROSLAG). Granulated Blastfurnace Slag: Technical Leaflet No. 1. In EUROSLAG; 2003.

(24) U.S. Geological Survey. Mineral Commodity Summaries 2018; U.S. Department of the Interior: Reston, VA, 2018; p 200.

(25) Renforth, P. The negative emission potential of alkaline materials. Nat. Commun. 2019, 10, 1401.

(26) Chang, E. E.; Pan, S.-Y.; Chen, Y.-H.; Chu, H.-W.; Wang, C.-F.; Chiang, P.-C. CO2 sequestration by carbonation of steelmaking slags in an autoclave reactor. J. Hazard. Mater. 2011, 195, 107-114.

(27) Baciocchi, R.; Capobianco, O.; Costa, G.; Morone, M.; Zingaretti, D. Carbonation of Industrial Residues for CO2 Storage and Utilization as a Treatment to Achieve Multiple Environmental Benefits. Energy Procedia 2014, 63, 5879-5886.

(28) Yildirim, I. Z.; Prezzi, M. Chemical, Mineralogical, and Morphological Properties of Steel Slag. Advances in Civil Engineering 2011, 2011, 13.

(29) Piatak, N. M.; Parsons, M. B.; Seal, R. R. Characteristics and environmental aspects of slag: A review. Appl. Geochem. 2015, 57, 236266.

(30) Motz, H.; Geiseler, J. Products of steel slags: An opportunity to save natural resources. Waste Manage. 2001, 21 (3), 285-293.

(31) Dippenaar, R. Industrial uses of slag (the use and re-use of iron and steelmaking slags). Ironmaking Steelmaking 2005, 32 (1), 35-46.

(32) Su, T.-H.; Yang, H.-J.; Shau, Y.-H.; Takazawa, E.; Lee, Y.-C. CO2 sequestration utilizing basic-oxygen furnace slag: Controlling factors, reaction mechanisms and V-Cr concerns. J. Environ. Sci. 2016, 41, 99111.

(33) Quaghebeur, M.; Nielsen, P.; Horckmans, L.; Van Mechelen, D. Accelerated Carbonation of Steel Slag Compacts: Development of High-Strength Construction Materials. Front. Energy Res. 2015, 3, 00052.

(34) Ko, M.-S.; Chen, Y.-L.; Jiang, J.-H. Accelerated carbonation of basic oxygen furnace slag and the effects on its mechanical properties. Construction and Building Materials 2015, 98, 286-293.

(35) Ghacham, A. B.; Pasquier, L.-C.; Cecchi, E.; Blais, J.-F.; Mercier, G. CO2 sequestration by mineral carbonation of steel slags under ambient temperature: parameters influence, and optimization. Environ. Sci. Pollut. Res. 2016, 23 (17), 17635-17646.

(36) Gunning, P. J.; Hills, C. D.; Carey, P. J. Accelerated carbonation treatment of industrial wastes. Waste Manage. 2010, 30 (6), 10811090.

(37) Chang, E. E.; Chiu, A.-C.; Pan, S.-Y.; Chen, Y.-H.; Tan, C.-S.; Chiang, P.-C. Carbonation of basic oxygen furnace slag with metalworking wastewater in a slurry reactor. Int. J. Greenhouse Gas Control 2013, 12, 382-389. 
(38) Baciocchi, R.; Costa, G.; Di Gianfilippo, M.; Polettini, A.; Pomi, R.; Stramazzo, A. Thin-film versus slurry-phase carbonation of steel slag: $\mathrm{CO} 2$ uptake and effects on mineralogy. J. Hazard. Mater. 2015, 283, 302-313.

(39) Power, M. I.; McCutcheon, J.; Harrison, L. A.; Wilson, A. S.; Dipple, M. G.; Kelly, S.; Southam, C.; Southam, G. Strategizing Carbon-Neutral Mines: A Case for Pilot Projects. Minerals 2014, 4 (2), 399.

(40) Wilson, S. A.; Dipple, G. M.; Power, I. M.; Thom, J. M.; Anderson, R. G.; Raudsepp, M.; Gabites, J. E.; Southam, G. Carbon Dioxide Fixation within Mine Wastes of Ultramafic-Hosted Ore Deposits: Examples from the Clinton Creek and Cassiar Chrysotile Deposits, Canada. Econ. Geol. Bull. Soc. Econ. Geol. 2009, 104 (1), 95112.

(41) Wilson, S. A.; Harrison, A. L.; Dipple, G. M.; Power, I. M.; Barker, S. L. L.; Ulrich Mayer, K.; Fallon, S. J.; Raudsepp, M.; Southam, G. Offsetting of $\mathrm{CO} 2$ emissions by air capture in mine tailings at the Mount Keith Nickel Mine, Western Australia: Rates, controls and prospects for carbon neutral mining. Int. J. Greenhouse Gas Control 2014, 25, 121-140.

(42) Piatak, N. M.; Seal, R. R. Mineralogy and Environmental Geochemistry of Historical Iron Slag, Hopewell Furnace National Historic Site, Pennsylvania, USA. Appl. Geochem. 2012, 27 (3), 623643.

(43) Buchwald, V. F.; Wivel, H. Slag Analysis as a Method for the Characterization and Provenancing of Ancient Iron Objects. Mater. Charact. 1998, 40 (2), 73-96.

(44) Benvenuti, M.; Orlando, A.; Borrini, D.; Chiarantini, L.; Costagliola, P.; Mazzotta, C.; Rimondi, V. Experimental smelting of iron ores from Elba Island (Tuscany, Italy): Results and implications for the reconstruction of ancient metallurgical processes and iron provenance. Journal of Archaeological Science 2016, 70, 1-14.

(45) Pan, S.-Y.; Chiang, A.; Chang, E. E.; Lin, Y.-P.; Kim, H.; Chiang, P.-C. An Innovative Approach to Integrated Carbon Mineralization and Waste Utilization: A Review. Aerosol Air Qual. Res. 2015, 15, 10721091.

(46) Pan, S.-Y.; Ling, T.-C.; Park, A.-H. A.; Chiang, P.-C. An Overview: Reaction Mechanisms and Modelling of $\mathrm{CO} 2$ Utilization via Mineralization. Aerosol Air Qual. Res. 2018, 18 (4), 829-848.

(47) Gadikota, G.; Park, A.-h. A. Chapter 8 - Accelerated Carbonation of Ca- and Mg-Bearing Minerals and Industrial Wastes Using $\mathrm{CO}_{2}$. In Carbon Dioxide Utilisation; Styring, P., Quadrelli, E. A., Armstrong, K., Eds.; Elsevier: Amsterdam, 2015; pp 115-137.

(48) Mayes, W. M.; Riley, A. L.; Gomes, H. I.; Brabham, P.; Hamlyn, J.; Pullin, H.; Renforth, P. Atmospheric CO2 sequestration in iron and steel slag: Consett, Co. Durham, UK. Environ. Sci. Technol. 2018, 52, 7892.

(49) Harber, A. J.; Forth, R. A. The contamination of former iron and steel works sites. Environ. Geol. 2001, 40 (3), 324-330.

(50) Wilson, A. S. The Consett Iron Company Limited: A Case Study in Victorian Business History; University of Durham: Durham, U.K., 1973.

(51) Butler, B. C. M. Al-rich pyroxene and melilite in a blast-furnace slag and a comparison with the Allendre Meteorite. Mineral. Mag. 1977, 41 (320), 493.

(52) Kogel, J. E.; Trivedi, N. C.; Barker, J. M.; Krukowski, S. T. Industrial Minerals \& Rocks: Commodities, Markets, and Uses; Society for Mining Metallurgy and Exploration: Englewood, CO, 2006.

(53) Evans, A. M. Ore Geology and Industrial Minerals: An Introduction; Wiley, 2009.

(54) Proctor, D. M.; Fehling, K. A.; Shay, E. C.; Wittenborn, J. L.; Green, J. J.; Avent, C.; Bigham, R. D.; Connolly, M.; Lee, B.; Shepker, T. O.; Zak, M. A. Physical and Chemical Characteristics of Blast Furnace, Basic Oxygen Furnace, and Electric Arc Furnace Steel Industry Slags. Environ. Sci. Technol. 2000, 34 (8), 1576-1582.

(55) Geiseler, J. Use of steelworks slag in Europe. Waste Manage. 1996, 16 (1), 59-63.

(56) Zivanovic, V. XRF analysis of mineralogical matrix effects and differences between pulverized and fused ferromanganese slag. Chem. Ind. Chem. Eng. Q. 2011, 17 (2), 231-237.
(57) Washbourne, C. L. Ground Engineering Using Waste Materials; University of Newcastle Upon Tyne: Newcastle upon Tyne, U.K., 2009. (58) Scott, P. W.; Critchley, S. R.; Wilkinson, F. C. F. The chemistry and mineralogy of some granulated and pelletized blastfurnace slags. Mineral. Mag. 1986, 50, 141-147.

(59) Wang, Z.; Ni, W.; Li, K.; Huang, X.; Zhu, L. Crystallization characteristics of iron-rich glass ceramics prepared from nickel slag and blast furnace slag. Int. J. Miner., Metall. Mater. 2011, 18 (4), 455.

(60) Hall, C.; Large, D. J.; Adderley, B.; West, H. M. Calcium leaching from waste steelmaking slag: Significance of leachate chemistry and effects on slag grain mineralogy. Miner. Eng. 2014, 65, 156-162.

(61) Renforth, P.; Washbourne, C. L.; Taylder, J.; Manning, D. A. C. Silicate Production and Availability for Mineral Carbonation. Environ. Sci. Technol. 2011, 45 (6), 2035-2041.

(62) Huijgen, W. J. J.; Comans, R. N. J. Carbon dioxide sequestration by mineral carbonation Literature Review update 2003-2004 (ECN-C--05022); Energy Research Centre of the Netherlands; Petten, The Netherlands; 2005; p 37.

(63) Huijgen, W. J. J.; Witkamp, G.-J.; Comans, R. N. J. Mechanisms of aqueous wollastonite carbonation as a possible $\mathrm{CO} 2$ sequestration process. Chem. Eng. Sci. 2006, 61 (13), 4242-4251.

(64) Baciocchi, R.; Costa, G.; Di Bartolomeo, E.; Polettini, A.; Pomi, R. Carbonation of Stainless Steel Slag as a Process for CO2 Storage and Slag Valorization. Waste Biomass Valorization 2010, 1 (4), 467-477.

(65) Johnson, D. C.; Macleod, C. L.; Carey, P. J.; Hills, C. D. Solidification of stainless steel slag by accelerated carbonation. Environ. Technol. 2003, 24 (6), 671-678.

(66) Roadcap, G. S.; Kelly, W. R.; Bethke, C. M. Geochemistry of Extremely Alkaline $(\mathrm{pH}>12)$ Ground Water in Slag-Fill Aquifers. Groundwater 2005, 43 (6), 806-816.

(67) Engström, F.; Adolfsson, D.; Samuelsson, C.; Sandström, Å.; Björkman, B. A study of the solubility of pure slag minerals. Miner. Eng. 2013, 41, 46-52.

(68) Strandkvist, I.; Björkman, B.; Engström, F. Synthesis and dissolution of slag minerals - a study of $\beta$-dicalcium silicate, pseudowollastonite and monticellite. Can. Metall. Q. 2015, 54 (4), 446-454.

(69) Baciocchi, R.; Costa, G.; Polettini, A.; Pomi, R. Effects of thinfilm accelerated carbonation on steel slag leaching. J. Hazard. Mater. 2015, 286, 369-378.

(70) Hobson, A. J.; Stewart, D. I.; Bray, A. W.; Mortimer, R. J. G.; Mayes, W. M.; Rogerson, M.; Burke, I. T. Mechanism of Vanadium Leaching during Surface Weathering of Basic Oxygen Furnace Steel Slag Blocks: A Microfocus X-ray Absorption Spectroscopy and Electron Microscopy Study. Environ. Sci. Technol. 2017, 51 (14), 7823-7830.

(71) Roy, A. Sulfur speciation in granulated blast furnace slag: An Xray absorption spectroscopic investigation. Cem. Concr. Res. 2009, 39 (8), 659-663.

(72) Polettini, A.; Pomi, R.; Stramazzo, A. Carbon sequestration through accelerated carbonation of BOF slag: Influence of particle size characteristics. Chem. Eng. J. 2016, 298, 26-35.

(73) Ruiz-Agudo, E.; King, H. E.; Patiño-López, L. D.; Putnis, C. V.; Geisler, T.; Rodriguez-Navarro, C.; Putnis, A. Control of silicate weathering by interface-coupled dissolution-precipitation processes at the mineral-solution interface. Geology 2016, 44 (7), 567-570.

(74) Hellmann, R.; Wirth, R.; Daval, D.; Barnes, J.-P.; Penisson, J.-M.; Tisserand, D.; Epicier, T.; Florin, B.; Hervig, R. L. Unifying natural and laboratory chemical weathering with interfacial dissolution-reprecipitation: A study based on the nanometer-scale chemistry of fluid-silicate interfaces. Chem. Geol. 2012, 294-295, 203-216.

(75) Stewart, D. I.; Bray, A. W.; Udoma, G.; Hobson, A. J.; Mayes, W. M.; Rogerson, M.; Burke, I. T. Hydration of dicalcium silicate and diffusion through neo-formed calcium-silicate-hydrates at weathered surfaces control the long-term leaching behaviour of basic oxygen furnace (BOF) steelmaking slag. Environ. Sci. Pollut. Res. 2018, 25 (10), 9861-9872.

(76) Santos, R. M.; Ling, D.; Sarvaramini, A.; Guo, M.; Elsen, J.; Larachi, F.; Beaudoin, G.; Blanpain, B.; Van Gerven, T. Stabilization of 
basic oxygen furnace slag by hot-stage carbonation treatment. Chem. Eng. J. 2012, 203, 239-250.

(77) Ghorbani, Y.; Becker, M.; Mainza, A.; Franzidis, J.-P.; Petersen, J. Large particle effects in chemical/biochemical heap leach processes - A review. Miner. Eng. 2011, 24 (11), 1172-1184.

(78) Fagerlund, J.; Highfield, J.; Zevenhoven, R. Kinetics studies on wet and dry gas-solid carbonation of $\mathrm{MgO}$ and $\mathrm{Mg}(\mathrm{OH}) 2$ for $\mathrm{CO} 2$ sequestration. RSC Adv. 2012, 2 (27), 10380-10393.

(79) Zevenhoven, R.; Kohlmann, J.; Mukherjee, A. Direct dry mineral carbonation for $\mathrm{CO}_{2}$ emissions reduction in Finland. 27th International Technical Conference on Coal Utilization \& Fuel Systems; Clearwater, FL, 2002.

(80) Said, A.; Mattila, H.-P.; Järvinen, M.; Zevenhoven, R. Production of precipitated calcium carbonate (PCC) from steelmaking slag for fixation of CO2. Appl. Energy 2013, 112, 765-771.

(81) Dri, M.; Sanna, A.; Maroto-Valer, M. M. Mineral carbonation from metal wastes: Effect of solid to liquid ratio on the efficiency and characterization of carbonated products. Appl. Energy 2014, 113, 515523.

(82) Bilen, M.; Altiner, M.; Yildirim, M. Evaluation of steelmaking slag for $\mathrm{CO} 2$ fixation by leaching-carbonation process. Part. Sci. Technol. 2018, 36 (3), 368-377.

(83) Met Office Albemarle Climate. https://www.metoffice.gov.uk/ public/weather/climate/gcy9j0p48 (accessed January 17, 2019).

(84) Fernández Bertos, M.; Simons, S. J. R.; Hills, C. D.; Carey, P. J. A review of accelerated carbonation technology in the treatment of cement-based materials and sequestration of CO2. J. Hazard. Mater. 2004, 112 (3), 193-205.

(85) Riley, A. L.; Mayes, W. M. Long-term evolution of highly alkaline steel slag drainage waters. Environ. Monit. Assess. 2015, 187 (7), 463.

(86) Walker, C. S.; Sutou, S.; Oda, C.; Mihara, M.; Honda, A. Calcium silicate hydrate $(\mathrm{C}-\mathrm{S}-\mathrm{H})$ gel solubility data and a discrete solid phase model at $25^{\circ} \mathrm{C}$ based on two binary non-ideal solid solutions. Cem. Concr. Res. 2016, 79, 1-30.

(87) Bodor, M.; Santos, R. M.; Kriskova, L.; Elsen, J.; Vlad, M.; Van Gerven, T. Susceptibility of mineral phases of steel slags towards carbonation: mineralogical, morphological and chemical assessment. Eur. J. Mineral. 2013, 25 (4), 533-549.

(88) Douglas, G. B.; Wendling, L. A.; Coleman, S. Productive use of steelmaking by-product in environmental applications (I): Mineralogy and major and trace element geochemistry. Miner. Eng. 2012, 35, 4956.

(89) Yadav, S.; Mehra, A. Experimental study of dissolution of minerals and $\mathrm{CO} 2$ sequestration in steel slag. Waste Manage. 2017, 64, 348-357.

(90) Gautier, M.; Poirier, J.; Bodénan, F.; Franceschini, G.; Véron, E. Basic oxygen furnace (BOF) slag cooling: Laboratory characteristics and prediction calculations. Int. J. Miner. Process. 2013, 123, 94-101.

(91) Tossavainen, M.; Engstrom, F.; Yang, Q.; Menad, N.; Lidstrom Larsson, M.; Bjorkman, B. Characteristics of steel slag under different cooling conditions. Waste Manage. 2007, 27 (10), 1335-1344.

(92) Divsholi, B. S.; Lim, T. Y. D.; Teng, S. Durability Properties and Microstructure of Ground Granulated Blast Furnace Slag Cement Concrete. Int. J. Concr. Struct. Mater. 2014, 8 (2), 157-164.

(93) Shi, C. Steel Slag - Its Production, Processing, Characteristics, and Cementitious Properties. J. Mater. Civ. Eng. 2004, 16 (3), 230-237.

(94) Wedding, P.; Hogan, F.; Meusel, J. Evaluation for Durability and Strength Development of a Ground Granulated Blast Furnace Slag. Cem., Concr., Aggregates 1981, 3, 40-52.

(95) Taylor, R.; Richardson, I. G.; Brydson, R. M. D. Composition and microstructure of 20-year-old ordinary Portland cement-ground granulated blast-furnace slag blends containing 0 to $100 \%$ slag. Cem. Concr. Res. 2010, 40 (7), 971-983.

(96) Gan, L.; Zhang, C.; Shangguan, F.; Li, X. A Differential Scanning Calorimetry Method for Construction of Continuous Cooling Transformation Diagram of Blast Furnace Slag. Metall. Mater. Trans. B 2012, 43 (3), 460-467.
(97) Luxán, M. P.; Sotolongo, R.; Dorrego, F.; Herrero, E. Characteristics of the slags produced in the fusion of scrap steel by electric arc furnace. Cem. Concr. Res. 2000, 30 (4), 517-519.

(98) European Slag Association (EUROSLAG) Statistics 2016. http://www.euroslag.com/products/statistics/2016/ (accessed January 18,2018$)$.

(99) Kuhlman, L. R. Windrow composting of agricultural and municipal wastes. Resources, Conservation and Recycling 1990, 4 (1), 151-160.

(100) Lors, C.; Damidot, D.; Ponge, J. F.; Périé, F. Comparison of a bioremediation process of $\mathrm{PAHs}$ in a $\mathrm{PAH}$-contaminated soil at field and laboratory scales. Environ. Pollut. 2012, 165, 11-17.

(101) Bayless, E. R.; Schulz, M. S. Mineral precipitation and dissolution at two slag-disposal sites in northwestern Indiana, USA. Environ. Geol. 2003, 45 (2), 252-261.

(102) Schwab, A. P.; Hickey, J.; Hunter, J.; Banks, M. K. Characteristics of Blast Furnace Slag Leachate Produced Under Reduced and Oxidized Conditions. J. Environ. Sci. Health, Part A: Toxic/Hazard. Subst. Environ. Eng. 2006, 41 (3), 381-395. 